\title{
Caves of Indiana: A release of an important publication to mark the International Year of Caves and Karst
}

\author{
Richard L. Powell' ${ }^{1}$ Lee J. Florea ${ }^{1}$, and Arthur N. Palmer ${ }^{2}$ \\ ${ }^{1}$ Indiana Geological and Water Survey, Indiana University, Bloomington, Indiana \\ 2 State University of New York, Oneonta, New York \\ E-mail: Iflorea@indiana.edu \\ Received 10/1/2021 \\ Accepted for publication 10/22/2021 \\ Published 10/27/2021 \\ Suggested citation: Powell, R.L., Florea, L.J., and Palmer, A.N., 2021, Caves of \\ Indiana: A release of an important publication to mark the International Year of \\ Caves and Karst, Indiana Geological and Water Survey, Indiana Journal of Earth \\ Sciences, v. 3. DOI 10.14434/ijes.v3i1.33407
}

\author{
RELATED MATERIALS \\ "Caves of Indiana," R.L. Powell (edited \\ by L.J. Florea), 2021, http://hdl.handle. \\ net/2022/26858 \\ "A Guide to Caves and Karst of Indiana," \\ S.S. Frushour, 2012, http://hdl.handle. \\ net/2022/26859 \\ "Miscellaneous Map 11, Map of the Wy- \\ andotte Cave System," 2018, https:// \\ igws.indiana.edu/bookstore/details. \\ cfm?ltemID=3875\&Pub_Num=MM111
}

\section{PREFACE}

The year 2021 is the $60^{\text {th }}$ anniversary of the first publication of Caves of Indiana by Richard L. "Dick" Powell. To commemorate that anniversary, the Indiana Geological and Water Survey (IGWS) is releasing a digital version of this book. This release also coincides with the International Year of Caves and Karst sponsored by the United Nations Educational, Scientific and Cultural Organization (UNESCO). This paper includes a link to the digital book, a memoir from Dick, and a preface from Art Palmer (a mentor of mine and mentee of Dick's). Another version of Dick's memoir was recently printed in Volume 23, no. 2 of the Bloomington Indiana Grotto Newsletter.

Caves of Indiana has an interesting legacy in the IGWS and a lore among cavers in Indiana.

This paper tells that legacy from Dick Powell's point of view.

For many, Caves of Indiana represents a masterpiece of information during the birth of American speleology. For others, it is an archetype of publications that have damaged caves and relationships between cavers and landowners. Regardless, it is highly recognized for its data gathering and presentation. Many libraries refuse to carry a copy lest it be stolen. ${ }^{1}$ Copies often appear in personal libraries, sometimes with folded pages and broken spines.

I have accumulated a few gifted copies of my own.

This version was carefully revised and redacted to assure that the locations of, directions to, and maps of caves on private land are not available. In this, we attempt to balance the important, and often at odds, need to disseminate accurate information on caves while protecting this important, and frequently overlooked, fragile natural resource.

For more information about caves and karst, and guides to responsible caving, please consult with the National Speleological Society (http://www.caves.org), the National Cave and Karst Research Institute (http://www. nckri.org), or caving clubs local to your area.

—L.J. Florea, October 1, 2021

1 Paraphrased interview notes from Barbara Hill, recently retired Survey photographer: DNR told us possibly around 1990 to stop selling it because of the number of cave rescues and that people were finding cavers on their property—well, not cavers, novices actually. Those rescued from caves often had IGS Circular 8 in their backpack. And so finally, the state put it together. We still were part of the Indiana Department of Natural Resources at that point, so they said, "Don't sell it anymore." The book then became a wanted commodity and we had to tell customers that "we can't release it the way it is." And so, it now sells online for a lot of money. I think there were like three copies at the IU library and somebody told me that they get checked out but they never get brought back. 


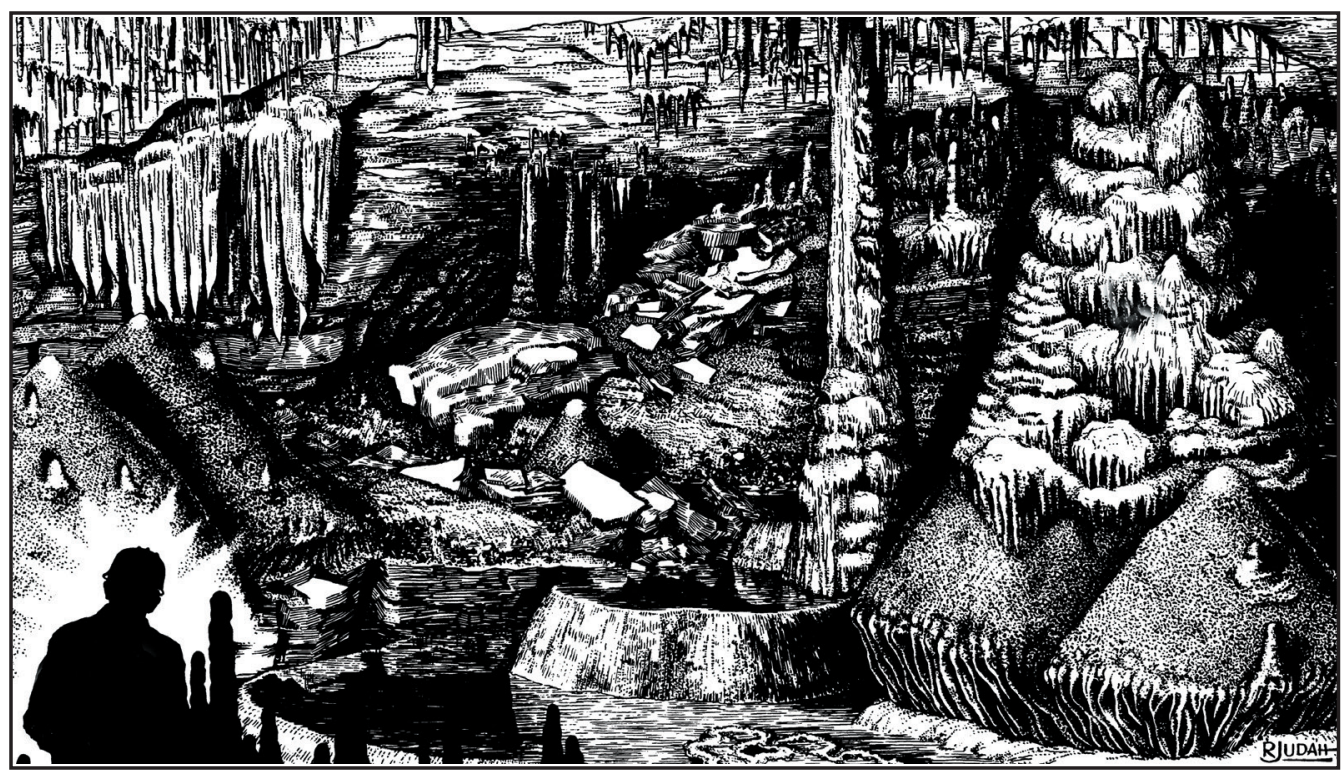

Figure 1. Drawing by Robert Judah included on page 18 of Caves of Indiana.

Editor's note: The IGWS has changed its name more than once during Dick Powell's career. Thus, the IGWS is simply referred to as the "Survey" to eliminate confusion.

\section{A TRIBUTE TO RICHARD L. POWELL}

In 1963, as I drove west to Bloomington, I pondered the fact that I would soon be living in a culture that was quite new to me. I was from the hills of western Massachusetts, with a geology BA, and had received a newly established U.S. government fellowship toward the Ph.D. in hydrogeology at Indiana University (IU). Was I prepared for it? It was not so much the science, but the abrupt shift in my personal world. My greatest (perhaps only) feeling of competence was an understanding of limestone caves and their origin. Indiana was a great cave area, and I had heard of one enthusiast there, Dick Powell, an MA grad from IU who had written a guidebook a few years before on Indiana caves, and who worked at the Survey. But how eager would he be to greet a Yank stepping onto his turf?

I found a warm, relaxed guy with a wide grin, looking up from a drafting table that contained a half-finished geologic map. I was impressed - he was a master draftsman. Seemingly with no effort at all, he could make geology come alive. Getting to know him, I quickly recognized his vast knowledge of caves, and the weird groundwater flow patterns in karst. He had no need for differential equations or technical wizardry. Best of all, he was happy to share his world and family. He was never my official advisor, but he unofficially more than filled that role, especially in understanding karst geomorphology.

Life was looking good.
I was not quite the wizard I was expected to be - a fairly good geologist and writer, but a loser in math and chemistry. Dick shared some of these quirks, so we got along just fine, and I was happy to follow his lead. Over the next four years he increased my understanding of karst and field techniques immensely, and I gladly absorbed it. I knew just a little of his early history (see his personal story that follows) but deeply impressed by his confidence, skill, and willingness to admit to minor quirks. At professional meetings Dick could blend into any group discussion of interest to him, even among total strangers.

One of his favorite quotes is: "If two things look the same, they've got to be different!" I've applied that bit of wisdom many times, regardless of how odd it sounds. Another skill is his quick understanding of what is needed to solve problems. Probably the best thing he passed on to me was the importance of mapping geomorphic levels, including how to obtain accurate vertical data and differences in elevation in caves. Previously, this kind of information was often omitted in routine cave surveys. But it's crucial, because cave morphology depends on the action of underground water, which in turn responds to gravity and elevation differences. Such measurements are bothersome in a cave, where one's usual concerns are falling, or getting lost or soaking wet. Instead, he showed how to relax and apply simple methods such as hand-leveling. These provide an easy path to what controls cave morphology, and thus karst hydrology. Without making a big issue about them, these are some of the lessons that Dick passed on to me, and which we later shared through mutual feedback.

On a karst field trip in my geomorphology class, I met my future wife, Peggy. We both spent much time with 
Dick, even after our 1967 migration to the Northeast, where I took a job teaching hydrogeology, geochemistry, and geophysics (ironically, all math-based) at the State University of New York, Oneonta campus. I spent a happy and highly successful 38 years there, sharing field work and student advisement with Peggy, but I'll never forget the paths that led me there.

Dick, meanwhile, went on for the Ph.D. at Purdue. He already knew far more than necessary and required only a few additional courses. He was well armed with the most important tools: common sense, broad knowledge of the field, and a powerful work ethic. We continued to share field trips, meetings, and social activities. Age is nibbling at all of us, but the core values remain.

Dick rarely toots his own horn, and then only faintly. Instead, he especially enjoys boosting the virtues of earlier geologists, his heroes, such as Clyde Malott, Ralph Esarey, Bill Wayne, and Charlie Wier. After a recent field trip to the Indiana karst at the 2018 Annual Meeting of the Geological Society of America, Dick grinned and whispered to me, "I got a chance to talk about Malott!"

I'm delighted that Dick remains affiliated with the Survey, together with several other venerable contemporaries with familiar names like Sam Frushour. It's like knowing that the world is still following its proper orbit. We should treasure their wisdom and historical perspective, because they all have much to share.

-A.N. Palmer, June 18, 2021

\section{A HISTORY OF CAVES OF INDIANA, IGS CIRCULAR 8}

My first cave visit was the boat trip into Donaldson Cave [ed., Upper Twin] in Spring Mill State Park in the summer of about 1946. I also went into the dry passage north of the entrance [ed., Bronson]. My mother, Mabel Powell, aunt, Gayle Tatlock, and I stayed in the park during a Tatlock family reunion in Salem, Indiana. We lived in Evansville, Indiana, at that time.

My mother had been a bookkeeper for several independent petroleum producers, eventually with Yingling Oil in first Evansville, then Oklahoma City, retiring in 1972 from their office in Amarillo, Texas. My aunt was the head secretary for Sun Oil Company after WWII. During my last year in high school, I worked for Jerry Robertson, the Tri-State Oil Reporter, as a draftsman of landowner and lease maps with well locations and a proofreader of the weekly oil report.
I enrolled at Indiana University (IU) as a geology major in the fall of 1953, following graduation from Evansville Central High School. Jerry suggested that I contact the petroleum section head of the Survey, Tom Dawson, for hourly work since I knew the Public Land Survey (PLS) system, the various geologic names of oil producing strata, and was a draftsman. My second day on campus, I asked Mr. Dawson about a job, but was told that he had hired hourly help for the semester the previous day. I next introduced myself to Ralph Esarey, a professor of petroleum geology and former Indiana state geologist (1936-1945). He did not have any work but suggested that I contact Charles Wier, coal section head of the Survey, with offices in the Louden House and employing three coal geologists, a paleobotanist, a glacial geologist, and two members of the publications section. Louden House existed where the northwest corner of Ballantine Hall is today on the Bloomington campus. Mr. Wier hired me as a draftsman for seven hours a week, the limit for a freshman, at 75 cents per hour. I later drafted a large map for Wier's dissertation and maps for other professors on campus at a higher pay rate.

Some 20 years later, I received a pin from IU for 15 years of service, and later added some other years, including one as the acting coal section head.

My first geology course at IU (physical geology) included a few pages of text and lectures on karst and cave features, mostly in southern Indiana and across the Ohio River in Kentucky. One of my earliest class friends was David Dale Phoenix, who had attended a meeting of the IU Caving Club in September of 1953 and suggested we join in October, which we did. That meeting was attended by several, including Marion S. Sharp, who had joined the previous month.

At that meeting, we learned that the next club field trip was to be Green Eye II Pit, about 65 feet deep. Dave and I did not want to look like amateurs, so we took his Ford sedan, sequestered at an undisclosed location, (freshmen were not allowed to have vehicles on campus), borrowed the club ladders ( $1 / 2$-inch manila rope with $1 \frac{3}{4}$-inch wooden rungs) and did Shaft Cave, about 75 feet deep with no safety line. Dumb!

After the trip to Green Eye II, I told Dave that I did not want to do any more caving if all caves had pit entrances. He said that many caves had walking or crawling entrances, and that I should look them up in the annual reports of the Indiana Department of Geology and Natural Resources located in the IU Geology library. I did, starting with Indiana Caves and Their Fauna by W.S. Blatchley (1897), and the Guide to Indiana Caverns by Esarey and Fix (1939), along with other reports. I kept 
notes on 3-inch by 5 -inch index cards. I cannot complain that Dave conned me into doing all of the "research" for caves inasmuch as he provided the transportation.

About November of 1953, my mother informed me that she was moving to Oklahoma City as the bookkeeper for Yingling Oil. I spent several weekends going to Evansville on a Greyhound bus to see her before she moved. Other trips were with my high school friend Dan Needler who drove from Butler University in Indianapolis through Bloomington to Evansville to see his girlfriend and future wife. Interestingly, Dan told me that he and Dave Phoenix were friends in Danville, Indiana, before Dan moved to Evansville our senior year. After my mom moved, I went to Evansville monthly to spend the weekend with Aunt Gayle and some high school friends.

In the meantime, caving was becoming a weekend habit. I remember trips to Coon, Sullivan, and, Saltpeter, but have forgotten many other trips.

One particular caver I remember was Bill Breck from El Paso, Texas, who attended classes at IU, worked a full shift at RCA making TVs, and caved on some weekends. The day after finals in spring 1954, he took me to Oklahoma City to pick up my mother, sleep, and then drive to Carlsbad Caverns, New Mexico. I remember that I had a cold and a toothache when we left Bloomington, and we stopped at a doctor's office on the way out of town so I could get $5 \mathrm{cc}$ of penicillin. My cold was gone by St. Louis, though I had lumps about the size of deviled eggs on my head, arms, and legs by the time we got to Rolla. My toothache was gone for at least ten years.

We got to Oklahoma City in time to take my mother to work that day. I slept most of that day, but we still headed for Carlsbad after supper. I did my share of the driving between naps.

We arrived at Carlsbad Caverns about mid-morning of the next day. My memory of our trip through the cave is dreamlike. I helped my mother, she said, over the rough spots, and I could close my eyes for several years afterward and visualize the detailed scenery along the path. Bill took us to the town of Carlsbad where we ate and then Mom and I took a Greyhound bus back to Oklahoma City and Bill drove home to El Paso. I slept almost all the way.

Thankfully, I did not need two more shots of penicillin! I slept a lot the following weeks, but finally updated petroleum borings on a regional map of the tri-state area for Jerry and bagged groceries at a nearby store.

I considered a transfer to Oklahoma State University to be close to my mother. The town was meager, the state geologist worked alone with a secretary in the geology building, the area was flat and nearly treeless, and the campus buildings were a thousand feet apart. So returned to IU the fall of 1954.

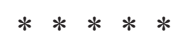

Dave Phoenix convinced me to become a member of the National Speleological Society (NSS) in May 1955, but he never did.

I dropped out of IU in December 1955 owing to low grades in math and chemistry. Marion quit because of an argument with a professor in the education department. We married on January 6, 1956, and moved into a two-room apartment in a two-story house where the parking lot for the Monroe County Public Library is now. Dave was my best man.

We attended some of the meetings of the IU Caving Club. I contributed an article on how to locate caves in Indiana using the PLS system in Volume 1 of their newsletter, The Cavern. William J. Wayne, Survey glacial geologist with an interest in karst and caves, became the club sponsor. Marion made money editing and rewriting term papers for IU students and working some evenings with concessions at the Von Lee Theater. I expanded my drafting business, worked a 32-hour-per-week job as a draftsman and illustrator for the IU Bureau of Business Research, and bused dishes most evenings in the Commons of the IU Memorial Union. We spent $\$ 325$ for a 1949 Ford on monthly payments about three months after we got married.

Our first daughter, Margaret Anne, was born September 4,1956 . I can only remember one cave we visited while Marion was about seven months pregnant. Jewel Box Cave on Richard Smoot's property in Harrison County required crossing two barbed wire fences about 150 feet apart, enclosing a dozen or so cattle. I held the two strands of wire apart, Marion slipped through and we crossed the other fence. Jewel Box lived up to its name, with numerous long soda straw stalactites and an assortment of stalagmites and columns. We headed back to the car and crossed the first fence. The cattle curiously trotted toward us, which frightened Marion, a city girl, whereas I had spent eight summers on a farm with 22 or so milk cows. We were temporarily surrounded, but I got her through the second fence with no problem.

$$
* * * * *
$$

Charles Wier, now Dr. Wier, walked through the Commons in the Memorial Union about 5:20 p.m. one evening in January 1957 while I was busing dishes. He asked me if 1 wanted a job with the coal section as a geologic assistant.

"Yes, sir!" 
So, I went to work drafting, collecting samples for chemical analysis from coal outcrops and surface and underground mines, and helping field geologists when they needed assistance. My salary was $\$ 50$ per week.

In early March, Charlie added to my workload. "Dick, you knowalotaboutcavesinIndianaandtheSurveyneedsapublication to answer requests for information about caves."

A prospectus was prepared (Appendix 1) and initialed by Charles Deiss, the state geologist. It was noted that much of the data existed in the annual reports of the Indiana Department of Conservation, and that I had already provided about 75 percent of the work needed. It was noted, however, that I needed time to get more information on some caves in Crawford, Harrison, and Washington counties. The estimated cost was about $\$ 1,000$ to cover per diem, mileage, drafting, and my salary.

I arranged two weeks of fieldwork with Don Burton and Jim Langhammer. Don accompanied me for caves in the Wyandotte Cave area of Crawford County and Cave River Valley in Washington County. I got cave information from Lloyd Kimble and we visited 12 caves in Washington County in one long day. Jim Langhammer was company for caves mostly in Harrison County, including about a half-mile of passage in Binkley's Cave. Information for Harrison was largely from Lewis Lamon of Corydon.

I notified other cavers scattered throughout Indiana that I was working on the project and visited other caves with them on weekends. I remember meeting during the summer of 1957 with some of the Central Indiana Grotto members (Robert Fredericks, Rubin Vig, Ed Lavigino, Arthur Davis, Charles Weimer, and possibly others) in Memorial Hall on the Bloomington campus to swap cave data and get approval for publishing the book.

One complicating factor at that time was that less than half of the areas of Indiana with caves were covered by published U.S. Geological Survey 7.5-minute topographic quadrangle maps. So, we used county road maps of Indiana, at a scale of 1 inch per mile, to locate caves with the help of U.S. Department of Agriculture aerial photography. The 7.5-minute topographic coverage for the area was complete by 1966.

$* * * * *$

I started writing Caves of Indiana in late March 1956 and submitted rough drafts to Charles Wier, Joe Guennel, and Harold Hutchison for critical review. The first draft, as best I can remember, covered about 125 caves. It also contained the ten rules of caving, a section which was deleted because "it did not fit in." I also was disappointed because the book was limited to six photographs because they had to be published as collotype prints from Boston. I wanted 30 or more less expensive, black-and-white half-tone prints. During an annual visit with Marion during the early 2000s to see Joe and Hilde Guennel in Littleton, Colorado, Joe apologized to me for agreeing to take out the safety rules and the limiting the photographs.

I used published sources along the way as a quick way to get information on known caves. The earliest reference was Blatchley (1896). Various articles on individual caves were occasionally published in the Proceedings of the Indiana Academy of Science. Other important guides of limited value were Esarey and Gordon Fix (1939) and "Caves of Indiana" by George F. Jackson (1954) in the NSS Bulletin.

I got the reviews back in early 1958 with requests for several revisions. Also, because the survey drafting section re-inked the cave maps, I insisted that every wiggle on the maps, mostly two lines in the wilderness, be exactly as I had drafted them. Furthermore, in the year that had transpired during the review, cavers had explored, described, and mapped several new caves. We decided that these new caves should be added. So, I did, resulting in a new total of 398 included caves. The revised manuscript was resubmitted to editorial review with the new cave maps added.

$$
* * * * *
$$

My geological career seemingly ended in September 1958.

Esarey, for whom I was drafting maps parttime, confronted me as I entered his office.

"Dick, you have to get a ticket or you will never get what you need." In other words, get a degree- geography, archaeology, or bean bag toss, it did not matter.

"You have very good grades in geography." He apparently had done some homework on me, possibly collaborating with Dr. Wier and Dr. William Thornbury, a geomorphology faculty member.

Esarey had even worked out a class schedule for me to get a bachelor's degree with no math, chemistry, or physics. However, I needed hours in a foreign language (German) in three semesters. We filled out a registration form for the semester, and he sent me next door to the geography department in Kirkwood Hall to get the chairperson's signature, followed by the Graduate Acceptance Office downstairs in Kirkwood to get enrolled. The department secretary was reluctant to let me see the chair, but I insisted that I had to get his signature.

Finally, she admitted me to his office. He was drunk. It was 10 a.m. 
I tried for ten minutes, shy of slapping him, to get his signature. I gave up and thanked the secretary as I left and went back to Esarey's office. As I closed the door to his outer office and before I even got into his office, he said, "What's wrong?"

"The son of a $\cdots .$. is drunk." This was language I never would have normally used in front of him.

He paused, standing, but as he sat down, he said, "Give me that card."

He signed his name and said, "Take this to the graduate office."

The woman in that office read the card, looked at me and said, "I will take care of it. You are admitted."

The chair of the geography department was also replaced.

Did Esarey or the graduate office cause his ouster? I have no doubt that Esarey, as the state geologist and therefore head of a state agency, had a long arm and more respect than some other professors on campus.

There were about 20 students in the IU geography department in 1958, but only two were from Indiana. I was one of those two. We both received stipends as staff cartographers. I took a few more geography, geology, and archeology classes, and updated Caves of Indiana two more times on my own nickel.

A good geographer can do anything!

Four years later I got a master's degree in geography, and raised my 0.92 GPA to a 2.92 out of 3.0. By then, my mother was in Amarillo, Texas, and could not make the trip, so I was pumping gas at Headly's Standard Oil Station during commencement in the spring of 1961.

$$
* * * * *
$$

Caves of Indiana was in printed in October 1961 as Survey Circular 8, with 127 pages listing 398 cave entrances, and including 6 photos and 58 figures, with maps of 49 caves. At the last minute, a dedication to Tom Arnold and Ralph Moreland was added to the second page. Tom and Ralph drowned in Showfarm Cave in Orange County on July 16, 1961, while collecting data for an Indiana Cave Capers guidebook [ed., Cave Capers is an annual weekend gathering for cavers].

When Maurice Biggs, then assistant state geologist, asked how many copies should be printed, I looked to other states for guidance. The first edition of Caves of Pennsylvania in the 1920s printed 5,000 and sold at roughly 25 cents. The revised and expanded edition in the 1930s printed about 25,000 copies and was out of print in the 1950s. Most of the other state surveys published 5,000 copies of their equivalent publications. The Survey initially printed 1,000 copies at $\$ 1$.

It sold out the first year.

The Survey then printed 2,000 copies the second year.

By the end, Caves of Indiana went through

10 printings and 13,000 copies - one of the most popular Survey publications.

William White reviewed the book in the NSS News in March of 1962 . He noted that the caves were located by the PLS system, which almost no one understood, but which covered most of Indiana. The PLS system was, at that time, understood by some land owners, surveyors, soils scientists, and some, but not all, geologists. That remains true today!

I continued to maintain cave location records, as well as descriptions and maps of the caves. Eventually, this information was entered on punch cards, printed, and distributed to various groups such as grottos (chapters) of the NSS. The data were relinquished in 1972 to Randy Jackson when I enrolled in a Ph.D. program at Purdue University. In the end, I received two degrees in geography at IU, a bachelor's in1959 and a master's in 1961, and went to Purdue in 1972 to get a Ph.D. in geosciences.

The publication and distribution of Caves of Indiana ceased in 1990, owing to complaints to John Hill by the Indiana Karst Conservancy (ICS), as signed by R. Keith Dunlap, ICS president, dated February 13, 1990, and by the Central Indiana Grotto (CIG), signed by Kevin Bruno, CIG chairman, dated February 21, 1990. The CIG letter suggested that it should be discontinued when the remaining stock was depleted.

This was done.

I basically concur with the ICS and CIG requests, but do not agree with their suggestion that Caves of Indiana led to significant cave vandalism, cave rescues, and land owner problems. In my view, the problems were caused by poor judgment by the individuals involved. Including the ten caving rules would have been helpful.

I also get the impression that more than a few cavers are cheap thieves. Caves of Indiana is or was one of the books most frequently stolen from Indiana libraries.

—R.L. Powell, last revision April 18, 2021 